\title{
Optimum Unit Sizing and Techno Economic Feasibility Investigation of Industrial Micro Grid Praful P. Chudasama" ${ }^{1}$, Dr. Chetan D. Kotwal ${ }^{2}$ \\ ${ }^{*}$ Research Scholar, Electrical Engineering Department, R K University, Rajkot, Gujarat, India ${ }^{2}$ Professor \& Head, Engineering Department, SVIT, Vasad, Gujarat, India
}

\begin{abstract}
In this research study, the techno-economic feasibility and optimal unit sizing are investigated under various hybrid sources for with and without grid Industrial microgrid to meet the industrial load requirement reliably, continuously and sustainably. The whole study also reduces the total system net present cost and least cost of energy (COE). A combination of PV-DG- without grid and PV-DG- with grid has been investigated for the Industrial micro grid. It has been found that the net present cost for PV-DG- without grid and PV-DG- with grid are Rs 1,97,42,78,784 and Rs 31,38,13,056 respectively. Cost of energy for PV-DG- without grid and PVDG- with grid are Rs/kWh 21.58 and Rs 2.63. The results are indicated that the proposed PV-DG with grid hybrid configuration is the most economical in terms of operating cost, net present cost and gases emissions for Industrial Microgrid located at Ankleshwar Gujarat.
\end{abstract}

Keywords : Solar PV, Cost of Energy, Industrial Microgrid.

\section{INTRODUCTION}

In response to the globe energy inadequacy and environmental pollution, renewable energy has been expected to play rising importance in power generation due mainly to their emission free, environmental friendly. Moreover, distributed generation (DG) technologies based on renewable energy can be considered as most feasible options for developing countries like India, where the power demand have significantly increased over the past decade in Industries.[1,2]

Maximizing the economic, technological, and environmental benefits has become one of the major concerns for studies on Industrial microgrid systems, because the operation modes of microgrids put in huge differences with conventional electric power systems, and the outputs power of renewable energy are greatly influenced by climatic, meteorological, and environmental. In past, many researchers have widely studied renewable -based microgrid systems. Mamaghani et al. [3] aimed at analyzing the application of renewable sources and diesel generators in a stand-alone microgrid system in off-grid villages in Colombia. Such a renewable sources -based microgrid would be the best candidate in rural areas where grids were not available for realizing off-grid electrification. Dihrab and Sopian [4] proposed a hybrid power system to generate power for grid connected applications in three cities in Iraq. Results showed that it is possible for Iraq to use the solar and wind energy to generate enough power for villages in the desert and rural areas. Jamshidi and Askarzadeh [5] presented a multi-objective design of a photovoltaic, fuel cell and diesel generator hybrid energy system to supply the power of an off-grid rural community in 
Kerman, South of Iran, with the presence of operating reserve and uncertainties.

HOMER Software is used for the optimization of the proposed hybrid power system. HOMER is used to analyze the physical behaviour of the power system and its life cycle cost, which includes its installation or capital cost and running cost over the entire life period of that Industrial Microgrid.

Therefore, this study focuses on looking for the optimal integration of available Solar PV and conventional fossil energy to supply electrical demand in a reliable manner and good economic benefit to the Industrial Microgrid. Both gridconnected and stand-alone microgrid scenarios were considered. On one hand, the power system's physical behaviours were modelled to apply the technical analysis. On the other hand, the life-cycle cost for installing and operating the system over its lifetime is used to be the main optimization objective to assess different designs of the microgrid system.

\section{METHODOLOGY}

The selection of study area and its renewable sources availability and the estimation of energy demands are allowed by the minimum desirable load in the study area as discussed below.

\section{A. Site Description and Load profile:}

A BEIL Infrastructure Limited, is an industry providing a state-of-the-art service for Common Hazardous Waste Treatment, Storage and Disposal Facility (CHWTSDF) at GIDC Ankleshwar, Gujarat, India having the geographical coordinates of $21.56 \mathrm{~N}$ and 73.10 E. Scaled Annual Average Load profile of Industry is $20000 \mathrm{KWh} /$ day, $1527 \mathrm{KW}$ peak demand and $833 \mathrm{KW}$ Avg demands for 24 hrs with constant \& continuous load profile and a load factor of $55 \%$. In this study, the day-to-day (10\%) and time step to time step $(20 \%)$ random variability of load is taken as zero. the figure 1 showing the yearly load profile of the site .The life of whole project considered 25 years with annual interest rate $6 \%$ considered for the various feasible combination of Microgrid.

\section{B. Meteorological data:}

Annual daily solar irradiation available within the study location is shown in Fig. 1. Highest solar irradiation is available as $6.70 \mathrm{kWh} / \mathrm{m} 2 /$ day in April month, whereas lowest a $4.220 \mathrm{kWh} / \mathrm{m} 2 /$ day was found in August month.

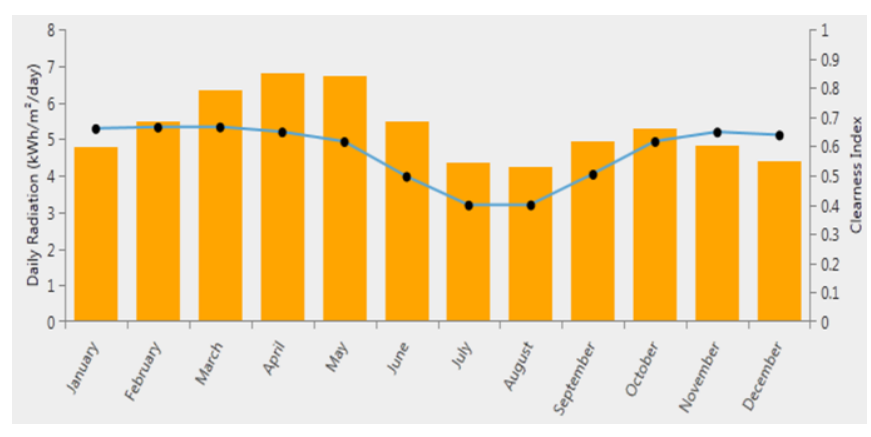

Figure 1: Annual daily solar irradiation available

\section{System Modelling:}

a. Solar PV Module:

Using the amount of solar radiation and the temperature available, the Solar PV output power can be calculated according to the following equation1, [6]

$$
P_{s p v}=S_{s p v} * f_{s p v}\left(\frac{R_{t}}{R_{t, s t d}}\left[1+\alpha_{p}\left(T_{c}-T_{c, s t d}\right)\right]--\right.
$$

Where,

Sspv $=$ The PV rated capacity under standard test conditions $(\mathrm{kW})$

fspv $=$ The derating factor of Solar PV.

$\mathrm{Rt}=$ The solar radiation incident on the PV array in the current time step $(\mathrm{kW} / \mathrm{m} 2)$

Rt,std $=$ The incident irradiance at standard test conditions $(1 \mathrm{~kW} / \mathrm{m} 2)$

$\alpha p=$ The temperature coefficient of power $(\% / o C)$. $\mathrm{Tc}=$ The temperature of the PV cell $(\mathrm{oC})$ in the current time step. 
Tc,std = The temperature of the PV cell under standard test conditions (25oc).

\section{b. Diesel generator:}

The diesel generator is used to provide the peak load demand of the system. Hourly Diesel consumption of diesel generator is expanded as below equation 2:[6]

$$
D G_{f u e l}(t)=\alpha * P_{R}+\beta * P(t)-----(2)
$$

Where,

DG fuel ( $t)=$ The fuel consumption of diesel generator

$P(t) I=$ the diesel generator power at a certain time

$\mathrm{PR}=$ the rated power of diesel generator

$\alpha, \beta=$ constants and range start from $0.08 \& 0.24$

\section{c. Net Present Cost (NPC):}

The total net present cost (NPC) of a system is the present value of all the costs the system incurs over its lifetime, minus the present value of all the revenue it earns over its lifetime. Costs include capital costs, replacement costs, O\&M costs, fuel costs, emissions penalties, and the costs of buying power from the grid.[6]

$C_{N P C}=\frac{C_{a n n, t o t}}{\operatorname{CRF}\left(i, R_{P r o j}\right)}$

Where $\mathrm{C}$ ann,tot is the total annualized cost, i the annual real interest rate (the discount rate), Rproj the project lifetime, and CRF is the capital recovery factor.

\section{d. Cost of Electricity (COE):}

COE is the ratio of total system discounted annualized cost to total energy served by the system (Eserve), which includes energy served to the load and energy supplied to the grid. COE is calculated by using Equation 4

$\operatorname{COE}=\frac{\operatorname{CRF}(\mathrm{i}, \mathrm{N}) \times C_{N P C}}{E_{\text {serve }}}$

Where $\mathrm{N}$ is the project lifetime. $\mathrm{C}_{\mathrm{NPC}}$, is the net present cost of the hybrid power system.
III. OPTIMISATION of MICROGRID

\section{a. Proposed Algorithm For Micro grid:}

The detailed algorithm steps to build the schematic and carry out Optimum unit sizing and techno-economic feasibility analysis.

1. Select different types of generators depending upon the availability of resources. Prior survey of site for available resources, load and existing generation is required for this purpose.

2. Decide maximum generation capacity for each type of generation. The attributes to be taken into account for this purpose can be reliability of Microgrid and operating reserve. Power exchange with grid can be additional attribute for energy deficit country.

3. Select incremental step size for each generator which is available commercially and generally installed. For example, DG systems are commercially available in the range of 500 $\mathrm{kW}$ to few MW. Hence, incremental step size can be set to $500 \mathrm{~kW}$ for DG generators.

4. Give priority to the DG source, i.e., from where the power should come first. For example, natural resources will be on higher priority as compared to fossil fuel based DGs.

5. Generate all possible combinations for selected generators, ranging from zero to maximum possible installation of each DG.

6. Check the generated combinations for validity. Each valid combination has to satisfy systems electrical requirement.

7. Calculate NPC and COE for each valid combination.

8. Find minimum of all NPC values and index corresponding to the minimum NPC.

9. The combination corresponding to minimum NPC is the optimal mix of the DGs. 


\section{b. Proposed Flowchart of Microgrid:}

When understand the system components and the equations, Modelling and simulations of the micro power system is carried out. Large number of options are available for different sizes of the components used, components to be added to the system which make sense, cost functions of components used in the system. Optimization and sensitivity analysis algorithms evaluated the possibility of system configuration. The system cost calculations account for costs such as capital, replacement, operation and maintenance, fuel and interest. Figure 2 indicates the schematic modeling for PV - Diesel hybrid system consisting of converter and load with and without grid connection.

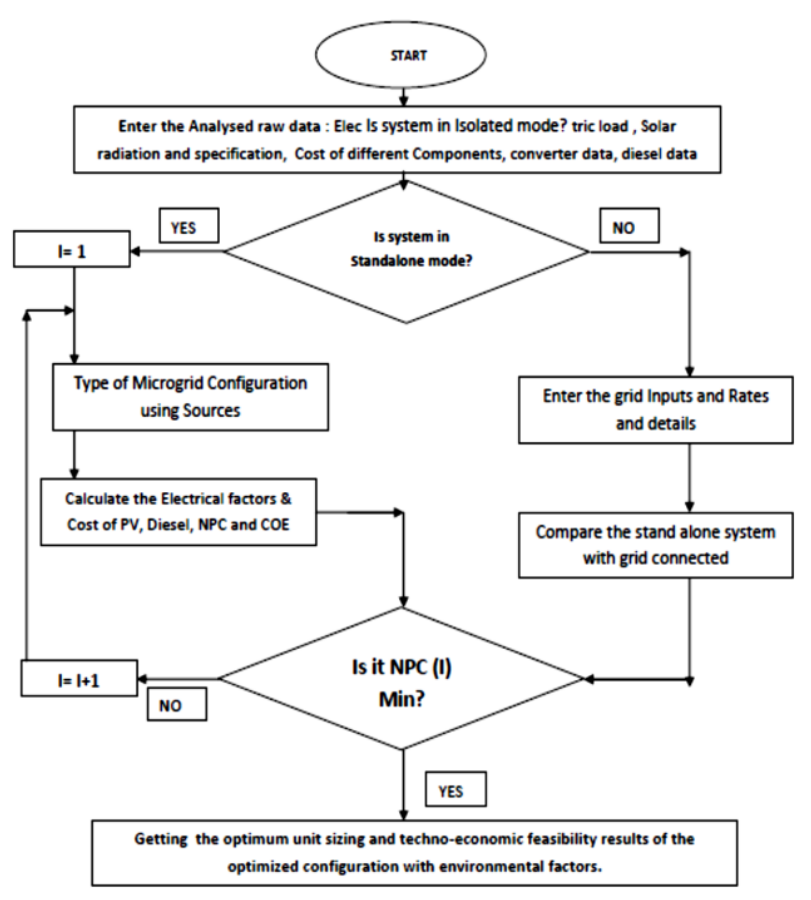

Figure 2: Proposed Flowchart of Microgrid

\section{c. Schematic Diagram of Industrial Micro grid and System Components Specification:}

Different combinations of renewable energy sources available in the study area evaluated through HOMER are shown in Fig. 8. The HRES comprises of solar PV generator (SPV),
Diesel Generator set, Converter. Figure 3 \& 4 shown PV- DG without Grid System and PVDG with Grid System respectively.

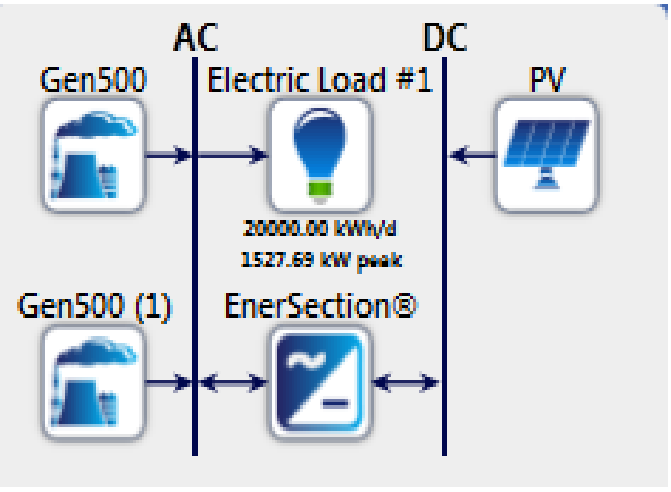

Figure 3: PV- DG without Grid System

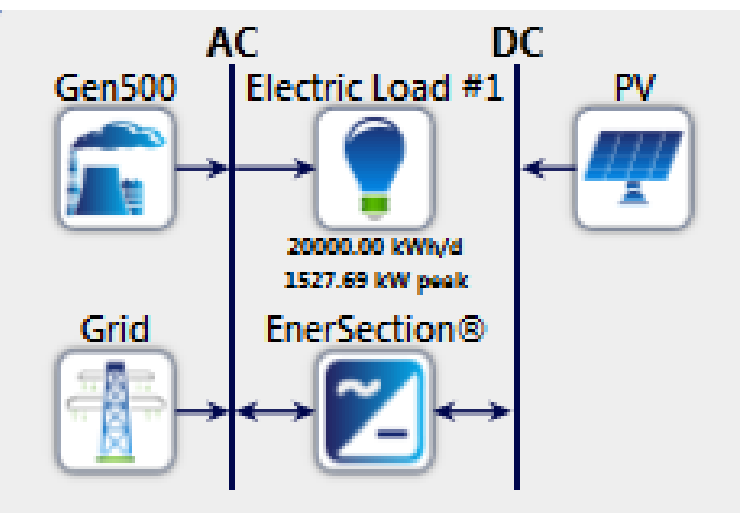

Figure 4: PV-DG with Grid System

Table 1 given the details of system components are used for Industrial Micro grid in HOMER for both configuration of Micro grid.

TABLE I

INPUT COMPONENT SPECIFICATIONS

\begin{tabular}{|l|c|}
\hline Description & Data description \\
\hline Solar PV module Model & $\begin{array}{c}\text { Generic flat plate } \\
\text { PV }\end{array}$ \\
\hline Rating $(\mathrm{kW})$ & 1 \\
\hline Derating factor (\%) & 80 \\
\hline & $\begin{array}{c}\text { No tracking - } \\
\text { Fixed }\end{array}$ \\
Tracking system & 20 \\
\hline Ground reflectance $(\%)$ & 22 \\
\hline Slope $\left({ }^{\circ} \mathrm{C}\right)$ & \\
\hline
\end{tabular}




\begin{tabular}{|l|c|}
$\begin{array}{l}\text { Efficiency at standard test } \\
\text { condition (\%) }\end{array}$ & 18 \\
\hline Life of Module (Year) & 25 \\
\hline Capital Cost (Rs/kW) & 40000 \\
\hline Replacement Cost (Rs/kW) & 30000 \\
\hline O\& M Cost (Rs/kW/Year) & 50 \\
\hline & \\
\hline Diesel Generator & \\
\hline DG Model & Generic \\
\hline Rating (kW) & 500 \\
\hline Min.Load Ratio (\%) & 25 \\
\hline Price of fuel per Litre in Rs & 61 \\
\hline Lifetime Operating Hours & 20000 \\
\hline Capital Cost (Rs/kW) & 7000 \\
\hline Replacement Cost (Rs/kW) & 6000 \\
\hline O\& M Cost (Rs/kW/Year) & 10 \\
\hline & \\
\hline Converter & \\
\hline Rating in kW & 100 \\
\hline Inverter Efficiency (\%) & \\
\hline Rectifier Efficiency (\%) & 90 \\
\hline Lifetime opearint Hours & \\
\hline Capital Cost (Rs/kW) & \\
\hline Replacement Cost (Rs/kW) & 5000 \\
\hline O\& M Cost (Rs/kW/Year) & \\
\hline & \\
\hline Grid & \\
\hline Grid Power Price (Rs/kWh) & \\
\hline Grid Sellback Price (Rs/kWh) & \\
\hline
\end{tabular}

\section{RESULTS AND DISCUSSION}

A HOMER analysis is used to simulate various schematics of Microgrid and then those schematics are simulated to find optimized Industrial Microgrid configuration with respect to operation cost, net present cost (NPC), cost of Energy (COE), gases emission and economic comparison etc.
TABLE III

COMPARISON OF OUTPUT RESULT OF VARIOUS PARAMETER OF BOTH CASES.

\begin{tabular}{|l|l|c|c|}
\hline \multicolumn{1}{|c|}{ Parameters } & \multicolumn{1}{|c|}{ Units } & Case 1 & Case 2 \\
\hline $\begin{array}{l}\text { Solar PV } \\
\text { Output }\end{array}$ & $\mathrm{kW}$ & 570 & 380 \\
\hline DG Output & $\mathrm{kW}$ & 1000 & 500 \\
\hline $\begin{array}{l}\text { Converter } \\
\text { Output }\end{array}$ & $\mathrm{kW}$ & 260 & 541 \\
\hline $\begin{array}{l}\text { PV } \\
\text { production }\end{array}$ & $\mathrm{kWh} /$ Year & 4988889 & 3325924 \\
\hline $\begin{array}{l}\text { Diesel } \\
\text { generator } \\
\text { production }\end{array}$ & $\mathrm{kWh} /$ Year & 4874667 & 0 \\
\hline Grid & $\mathrm{kWh} /$ Year & 0 & $45,64,674$ \\
\hline $\begin{array}{l}\text { Total } \\
\text { Production }\end{array}$ & $\mathrm{kWh} /$ Year & $82,00,591$ & $95,53,562$ \\
\hline $\begin{array}{l}\text { Fuel } \\
\text { consumption }\end{array}$ & $\mathrm{L} / \mathrm{year}$ & 1281743 & 0 \\
\hline NPC & $\mathrm{Rs}$ & 1974278784 & 313813056 \\
\hline COE & $\mathrm{Rs} / \mathrm{kWh}$ & 21.587 & 2.639 \\
\hline
\end{tabular}

In table II shown the comparisons of various technical parameters optimised output result of both cases. The COE of without grid case and withgrid case are Rs/kWh 21.587 and 2.63 respectively. The NPC for the first case for this proposed hybrid system is Rs 1974278784 and for the second case in which only grid is taken is Rs 313813056. The total yearly Solar PV production and consumption by load of the proposed both system is $4988889 \mathrm{kWh} / \mathrm{yr}$ and $3325924 \mathrm{kWh} / \mathrm{yr}$ respectively.

The following Table III Pollution emission can be analysed So, the pollutions emissions Carbon dioxide can greatly reduce in case 1 as compared to case 2 which is very useful in terms of environmental impact. 
TABLE IIIII

COMPARISON OF OUTPUT RESULT OF BOTH CASE WITH POLLUTION EMISSIONS

\begin{tabular}{|c|c|c|c|}
\hline Carbon dioxide & $\mathrm{kg} / \mathrm{yr}$ & 3375251 & 1618264 \\
\hline $\begin{array}{c}\text { Carbon } \\
\text { monoxide }\end{array}$ & $\mathrm{kg} / \mathrm{yr}$ & 8331 & 0 \\
\hline $\begin{array}{c}\text { Unburned } \\
\text { hydrocarbons }\end{array}$ & $\mathrm{kg} / \mathrm{yr}$ & 923 & 0 \\
\hline $\begin{array}{c}\text { Particulate } \\
\text { matter }\end{array}$ & $\mathrm{kg} / \mathrm{yr}$ & 628 & 0 \\
\hline Sulfur dioxide & $\mathrm{kg} / \mathrm{yr}$ & 6778 & 7016 \\
\hline Nitrogen oxides & $\mathrm{kg} / \mathrm{yr}$ & 74341 & 3431 \\
\hline
\end{tabular}

\section{CONCLUSION}

Two different configurations of hybrid renewable energy system are compared \& examined in this paper comprising of PV- DG without grid and PV - DG with grid. The whole study also reduces the total system net present cost and least cost of energy (COE). A combination of PV-DG- without grid and PV-DGwith grid has been investigated for the Industrial micro grid. It has been found that the net present cost for PV-DG- without grid and PV-DG- with grid are Rs 1,97,42,78,784 and Rs 31,38,13,056 respectively. Cost of energy for PV-DG- without grid and PV-DGwith grid are Rs/kWh 21.58 and Rs 2.63. The results are indicated that the proposed PV-DG with grid hybrid configuration is the most economical in terms of operating cost, net present cost and gases emissions for Industrial Microgrid located at Ankleshwar Gujarat

\section{VI.REFERENCES}

[1] He L, Chen YZ, Zhao HH, et al. Game-based analysis of energy-water nexus for identifying environmental impacts during Shale gas operations under stochastic input. Sci. Total Environ. 2018; 627:1585-601.
[2] Chen Y, Lu H, Li J, et al. Regional planning of new-energy systems within multiperiodand multi-option contexts: a case study of Fengtai, Beijing, China[J]. Renew Sustain Energy Rev 2016; 65:356-72.

[3] Mamaghani AH, Escandon SAA, Najafi B, et al. Techno-economic feasibility of photovoltaic, wind, diesel and hybrid electrification systems for off-grid rural electrification in Colombia. Renew Energy 2016;97:293-305.

[4] Dihrab SS, Sopian K. Electricity generation of hybrid PV/wind systems in Iraq. Renewable Energy 2010; 35:1303e7.

[5] Jamshidi, M., \& Askarzadeh, A.Techno-economic analysis and size optimization of an off-grid hybrid photovoltaic, fuel cell and diesel generator system. Sustainable Cities and Society 2018.

[6] Homer renewable energy software documentation.

http://www.homerenergy.com/documents/Microp owerSystemMode lingWithHOMER.pdf

\section{Cite this article as :}

Praful P. Chudasama, Dr. Chetan D. Kotwal, " Optimum Unit Sizing and Techno Economic Feasibility Investigation of Industrial Micro Grid , International Journal of Scientific Research in Science, Engineering and Technology(IJSRSET), Print ISSN : 2395-1990, Online ISSN : 2394-4099, Volume 6, Issue 2, pp.304-309, March-April-2019.

Doi : https://doi.org/10.32628/IJSRSET207491 Journal URL : http://ijsrset.com/IJSRSET207491 